DOI https://doi.org/10.15589/znp2020.4(482).3

УДК 621.9.011

\title{
"SOLIDWORKS PROFESSIONAL" PROGRAM AND SOME REGULARITIES OF HYDROBIONICS FOR UNDERWATER VEHICLES MODELS BUILDING
}

\section{ПРОГРАМА “SOLIDWORKS PROFESSIONAL" I ДЕЯКІ ЗАКОНОМIРНОСТI ГІДРОБІОНІКИ ДЛЯ ПОБУДОВИ МОДЕЛЕЙ ПІДВОДНИХ АПАРАТІВ}

\author{
Oksana M. Savinok ${ }^{1,2}$ \\ savoksamit12@gmail.com \\ ORCID: 0000-0002-4095-7267 \\ Katerina V. Marinicheva ${ }^{2}$ \\ k.marinicheva@ukr.net \\ ORCID: 0000-0001-6462-3643 \\ Viktor B. Yehorov ${ }^{1}$ \\ mechatronics.robotlab@gmail.com \\ ORCID: 0000-0003-4699-834X \\ Kirill B. Telpashov ${ }^{1}$ \\ kirichplay12345@gmail.com \\ ORCID: 0000-0002-4041-465X
}

\author{
О. М. Савінок ${ }^{1,2}$, \\ канд. техн. наук, доцент
}

К. В. Марінічева ${ }^{2}$, молодший науковий співробітник

в. Б. Сгоров ${ }^{1}$, канд. техн. наук, доцент

К. Б. Тельпашов ${ }^{1}$

\author{
${ }^{1}$ Odessa National Academy of Food Technologies, Odesa \\ ${ }^{2}$ Research Center of the Armed Forces of Ukraine "State Oceanarium" \\ of the Institute of Naval Forces of the National University "Odesa Maritime Academy”, Odesa \\ ${ }^{1}$ Одеська начіональна академія харчових технологій, м. Одеса \\ ${ }^{2}$ Науково-дослідний центтр Збройних сил Украӥни «Держсавний океанаріум» \\ Інституту Військово-Морських Сил Національного університету «Одеська морська академія», м. Одеса
}

\begin{abstract}
During designing models of static submarines at different depths, SolidWorks software was used, the licensed version of which is based on the laboratory "Mechatronics and Robotics" of the Odessa National Academy of Food Technologies. Tasks that were solved with the use of "SolidWorks Professional" software: 3D-model design, engineering analysis (strength, stability). Different parameters with length of models up to $3 \mathrm{~m}$ and diameter from 0,301 to $0,536 \mathrm{~m}$, also different shapes were used in the simulation. In accordance with the capabilities of the software, the models were tested under static conditions of pressure, which is created on the object $-0,505 \mathrm{MPa}$. To determine the possible kinematic characteristics of the simulated objects, a preliminary analysis of the geometric parameters was performed. The most perfect in terms of kinematic characteristics in the underwater environment are marine animals with certain body shapes. The main criterias for the analysis were the ratio of the relative distance from the bow to the widest part of the model to their total length and the relative thickness of the natural profiles.

The calculations of the analyzed parameters for the designed models allowed to affirm that the optimal values in models 13 and 15 . The shape and size of models 13 and 15 responds to the optimally established ratios for biological objects and may become a prototype for the further researches in the design of underwater robotic vehicles that will be widely used in researches and beyond. However for unambivalent conclusion about the nature of changes in the strength properties of the models and to analyze the impact of the environment on the object and the kinetics of the model in the aquatic environment, the additional tests in hydrodynamic and kinematic processes using variations of SolidWorks Simulation Xpress need to be carried out.
\end{abstract}

Key words: underwater vehicles; aquatic organisms; kinematic characteristics; 3D-modeling; parametric modeling.

Анотація. При проектуванні моделей статичних підводних апаратів на різних глибинах було використано програмне забезпечення SolidWorks, ліцензійна версія якого $€$ на базі лабораторії «Мехатроніки та робототехніки» Одеської національної академії харчових технологій. Завдання, які були вирішені за допомогою програмного забезпечення "SolidWorks Professional": 3D-проектування моделей, інженерний аналіз (міцність, стійкість). При моделюванні було використано різні параметри з довжиною до 3 м та діаметром від 0,301 до 0,536 м різної 
форми. Враховуючи можливості програмного забезпечення, було протестовано моделі в статичних умовах дії тиску, який при цьому створюється на об'єкт, - 0,505 МПа.

Для визначення можливих кінематичних характеристик у змодельованих об'єктів було проведено попередній аналіз їхніх геометричних параметрів. Найбільш досконалими за кінематичними характеристиками в підводному середовищі є морські тварини з певними формами тіл. Основними критеріями для аналізу були відношення відносної відстані від носової частини до найбільш широкої частини моделі, їх загальної довжини та відносна товщина природних профілів.

Проведені розрахунки аналізованих параметрів для спроектованих моделей дозволили встановити, що оптимальні значення були у моделей 13 та 15. Форма і розмір моделей 13 та 15 відповідають оптимально встановленим співвідношенням для біологічних об'єктів і можуть стати прототипом для подальших наукових доробок при проектуванні підводних роботизованих апаратів, які будуть широко використовуватися при проведенні наукових досліджень і не тільки. Однак для однозначного висновку щодо характеру змін міцностних властивостей моделей та для аналізу впливу середовища на об'єкт і кінетику руху моделі у водному середовищі необхідне проведення додаткових випробовувань в умовах гідродинамічних і кінематичних процесів із використанням варіацій програми SolidWorks Simulation Xpress.

Ключові слова: підводні апарати; гідробіонти; кінематичні характеристики; 3D-моделювання; параметричне моделювання.

\section{ПОСТАНОВКА ЗАДАЧІ}

3 давніх-давен дослідники природи захоплювалися, вивчали та намагалися відтворити біологічні об'єкти, досконалі й надзвичайно пристосовані до зовнішнього середовища. Отримані знання вони втілювали в різні технічні засоби, починаючи із простих і закінчуючи складними.

Спільними зусиллями біологів, фізиків, математиків, інженерів у XX ст. було сформувано новий напрям науки - біоніку. Сутність цієї науки зводиться до використання знань, отриманих у біології, для створення технічних об'єктів на нових фізичних принципах, запозичених у природи [1]. Якщо раніше час від вивчення біологічного об'єкту, визначення біонічних закономірностей до впровадження в технічні засоби рахувався десятиліттями, то нині він залежить від розвитку інформаційних технологій. Існуючі програмні продукти дозволяють звести до мінімуму часвід ідеї до готового виробу.

\section{АНАЛІЗ ОСТАННІХ ДОСЛІДЖЕНЬ І ПУБЛІКАЦІЙ}

Останніми десятиліттями об'єктами для вивчення стали гідро- і аеробіонти, тобто живі організми, які переміщаються у водному та повітряному середовищах. На відміну від технічних об'єктів, живі організми, які літають або плавають, здебільшого використовують рухомі рушії (крила, плавці), принцип дії яких ще не повністю вивчений [1].

Встановлення основних закономірностей біогідродинаміки має велике значення для сучасного авіа- та суднобудування. Предметами вивчення $є$ форма тіла тварини, ії зміни в процесі руху, руховий апарат, що створює тягу і підйомну силу, біоенергетика, характер обтікання рідини або повітря біля тіла тварини. Під час досліджень науковці розробляють фізичні та математичні моделі, на основі яких проводиться комп'ютерний експеримент, створюються технічні експериментальні установки.
Використання інноваційних систем 3D-моделювання дозволяє здійснювати проектування технічних засобів без необхідності у створенні матеріального прототипу, оцінити життєздатність моделі, iii слабкі сторони. Ринок програмних продуктів пропонує для цього різні варіанти.

Запропоновані провідними компаніями системи 3D-моделювання передбачають можливість внесення змін в об'єкт на різних етапах його створення. За традиційною схемою проєктування розробляється дерево побудови і керування розмірами 3D-моделі. В подальшому це дозволяє значно автоматизувати процес моделювання. Суттєвим недоліком необхідності планування процесу побудови $є$ уповільнення роботи на ранніх етапах моделювання і виключення можливості подальшого редактування через значну кількість конструктивних елементів [2].

Найбільш поширеними у машинобудуванні $\epsilon$ програмні продукти Solid Edge, AutoCAD, Autodesk i SolidWorks. Програмний продукт Solid Edge iз синхронною технологією, яка має багато переваг при конструюванні та редагуванні деталей і об'єкта загалом, забезпечує можливість прямого редагування геометричних параметрів, імпортованих геометричних форм, створених в іншому програмному ресурсі. Закладена в основу Solid Edge [2] синхронна технологія дозволяє фіксувати задум конструктора в моделі, за необхідності - вносити конкретні зміни. Так, процедурні елементи (отвори, округлення, масиви) можна легко редагувати, змінюючи їхні розміри, що значно спрощує вирішення задач автоматизації проектування. Синхронна технологія також дозволяє змінювати одночасно кілька деталей, моделюючи складальне креслення.

Для 2D- i 3D-проектування компанія Autodesk Inc. розробила програмний продукт Autodesk Inventor. Autodesk Inventor LT призначений для роботи лише з окремими деталями без можливості 
створення і документування складальних елементів [3]. Autodesk Inventor поєднує в одному спільному проектному просторі дані AutoCAD та 3D-моделі Inventor. Створення детальної 3D-візуалізації готової деталі, цифрові прототипи - це зручні засоби перевірки їх форм і характеристик перед створенням дослідних зразків і їх запуском у виробництво.

Технологія цифрових прототипів, реалізована в системі машинобудівельного 3D-проектування Autodesk Inventor, дозволяє отримати низку переваг і для користувачів традиційного AutoCAD. Inventor дозволяє поєднати в цифрових прототипах дані AutoCAD та 3D-моделі Inventor. Цифрові прототипи - зручний засіб перевірки форми і функціональності виробів перед створенням їх дослідних зразків. Програма Inventor допомогає повністю реалізувати досвід промислового проектування в AutoCAD, а існуючі наробки у вигляді проектних даних - у форматі DWG. До комплексів програмних засобів разом із Inventor входить остання версія AutoCAD Mechanical, яка використовується для ситуацій, коли користувачам потрібні інструменти для високопродуктивного 2D-креслення.

Перевагою технології цифрових прототипів Autodesk Inventor є швидкий доступ до даних у форматі DWG. Inventor обробляє їх напряму, без використання додаткових модулів перетворення. Отримана DWG-наробка може бути використана для створення узагальненої 3D-моделі деталей і відповідної ескізної документації. Для створення 3D-моделей виробів використовуються вихідні дані до проектування величини навантажень, швидкостей (для динамічних об'єктів), потужностей. За рахунок такої технології проектування отримані цифрові прототипи відразу перевіряють на коректність їх функціонування i з'ясовують наявність потенційних помилок до того, як виріб буде впроваджений у виробництво. Такі види креслень пов'язані із компонентами моделі, тому всі зміни деталей і виробів автоматично відображаються на кресленнях. У зв'язку з цим загальна тривалість від конструкторської ідеї до створення готової запчастини і об'єкта загалом буде зведена до мінімуму.

При внесенні змін здійснюється автоматичне оновлення усього проекту, що виключає необхідність ручних перерахунків кількості деталей, їх повторного маркування та класифікації. Отримані моделі можуть бути візуалізовані за рахунок використання модулю Autodesk Inventor Studio. Використання розширеної версії Autodesk Inventor Professional дозволяє підвищити якість виробів за рахунок можливості проводити динамічне моделювання з урахуванням навантажень, прискорень, моделювати 3D-проекти кабельних і трубопровідних систем у раніше спроектованих виробах. Аналогічно іншим файлам складальні креслення кабельних і трубопровідних систем оновлюються автоматично при внесенні змін у модель [4].
Ще один потужний засіб проектування SolidWorks, ядро інтегрованого комплексу автоматизації підприємства, за допомогою якого здійснюється підтримка виробу на всіх етапах життєвого циклу в повній відповідності із концепцією CALS-технологій [5] Основне призначення SolidWorks - забезпечення наскрізного процесу проектування, інженерного аналізу та підготовки виробництва виробів будь-якої складності і призначення, включаючи створення інтерактивної документації та забезпечення обміну даними з іншими системами.

Комплексні рішення SolidWorks базуються на передових технологіях гібридного параметричного моделювання, інтегрованих засобах електронного документообігу SolidWorks Enterprise PDM, а також на широкому спектрі спеціалізованих модулів. Програмне забезпечення має російську локалізацію, працює на платформі Windows XP\&Vista. Випуск конструкторської документації повністю відповідає вимогам ЄСКД. Завдяки потужним можливостям і доступній ціні система швидко впроваджується у виробництво, забезпечуючи швидку окупність вкладених коштів.

Програмний продукт SolidWorks дозволяє здійснювати твердотільне і поверхневе параметричне моделювання з одночасним керуванням моделлю. При проектуванні деталей $є$ можливість вибору матеріалу на базі його фізичних властивостей, динамічного внесення змін у режимі он-лайн, моделювання просторових трубопроводів і каналів з використанням тривимірних ескізів. Значну частку переваг SolidWorks надає при проектуванні складних моделей (десятки / сотні тисяч компонентів) різних габаритних розмірів iз круговими, лінійними і похідними масивами компонентів, вирізами і отворами як елементами складного креслення. SolidWorks забезпечує проектування виробів 3 урахуванням специфіки виготовлення із листових матеріалів 3 отриманням розгорток, зварних конструкцій, прес-форм і штампів.

\section{ВІДОКРЕМЛЕННЯ НЕ ВИРІШЕНИХ РАНІШЕ ЧАСТИН ЗАГАЛЬНОЇ ПРОБЛЕМИ}

Аналіз засобів проектування, якими найчастіше користуються конструктори, дозволив з'ясувати, що не всі програмні продукти ефективні при розробці об'єктів, які в процесі експлуатації будуть піддаватися навантаженням, здатні здійснювати експрес-аналіз міцності деталей і кінематики механізмів, визначення напружень, деформацій, розрахунок коефіцієнту запасу міцності, імітацію роботи механізмів, пошук взаємопроникнень та аналіз колізій між ланками; контактні взаємодії, вплив гравітації. Залежно від класу задач, які розв'язуються, замовникам пропонується три базових конфігурації системи: SolidWorks, SolidWorks Professional i SolidWorks Premium, доповненням до яких може бути варіація SolidWorks Simulation Xpress, яка дозволяе вирішувати перераховані завдання на етапі проєктування. 


\section{МЕТА ДОСЛІДЖЕННЯ}

Враховуючи ринкові пропозиції програмних продуктів для реалізації проектних рішень, метою цієї статті було вивчення можливостей застосування найбільш перспективного програмного продукту для створення моделей підводних апаратів на основі закономірностей гідробіоніки. У статті наведено результати моделювання та оцінювання міцностних характеристик апаратів, побудованих за допомогою конфігурації SolidWorks Professional (версія для учбових цілей, яка надається за запитом навчальним закладам).

\section{МЕТОДИ, ОБ'СКТ ТА ПРЕДМЕТ ДОСЛІДЖЕННЯ}

Об’єктом досліджения є моделі апаратів, форми яких максимально наближені до форм морських тварин. Предметом дослідження є програма SolidWorks Professional, закономірності гідробіоніки. При проектуванні моделей статичних підводних апаратів на різних глибинах було використано програмне забезпечення SolidWorks, ліцензійна версія якого
$€$ на базі лабораторії «Мехатроніки та робототехніки» Одеської національної академії харчових технологій. Завдання, які були вирішені за допомогою програмного забезпечення "SolidWorks Professional": 3D-проектування моделей, інженерний аналіз (міцність, стійкість). Використання закономірностей гідробіоніки полягало в попередньому аналізі геометричних параметрів спроектованих моделей. У роботі було використано метод формалізації, порівняння та системного аналізу.

\section{ОСНОВНИЙ МАТЕРІАЛ}

Як прототипи для створення моделей були використані форми морських тварин, їхі розміри та кінетичні характеристики. Приклади спроектованих моделей наведені в табл. 1. Довжини моделей варіювали від 1 м до 3 м, діаметр - від 0,301 до 0,536 м. Враховуючи можливості наданого програмного забезпечення, моделі були протестовані в статичних умовах дії тиску, який при цьому створюється на об’єкт, - 0,505 Мпа-5Атм.

Таблиця 1. Зображення спроектованих моделей

\begin{tabular}{|c|c|c|c|}
\hline № 3/II & Зображення моделі & № 3/II & Зображення моделі \\
\hline 1 & 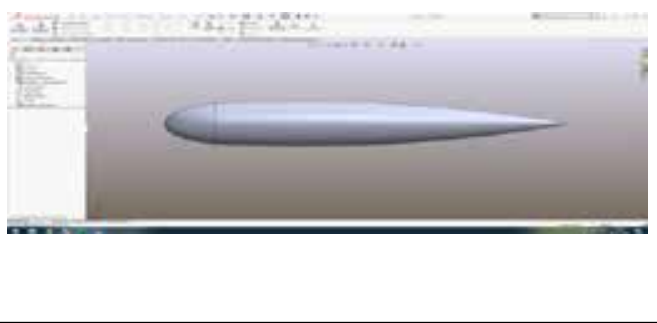 & 9 & 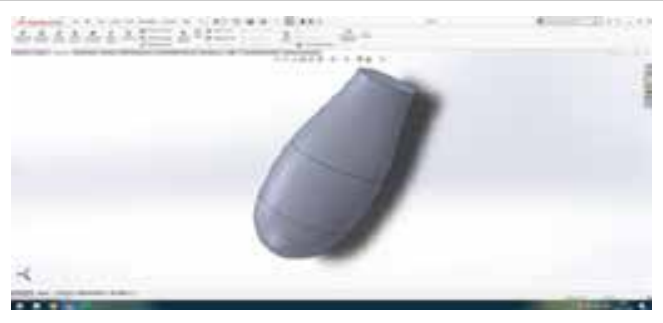 \\
\hline 2 & 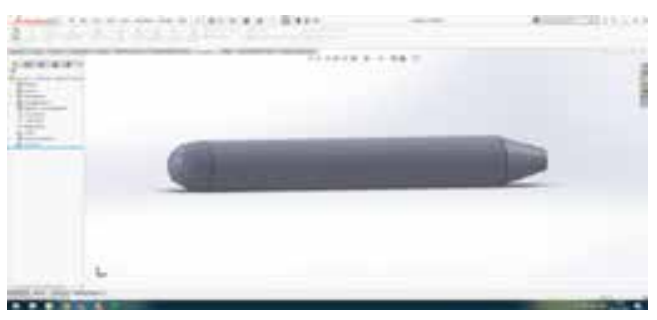 & 10 & 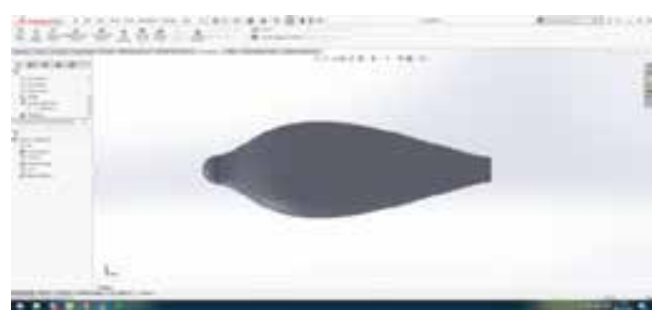 \\
\hline 3 & 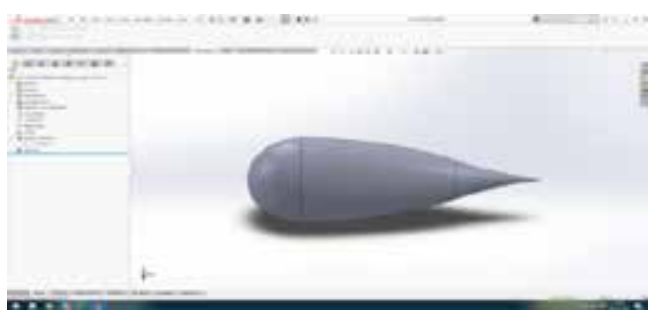 & 11 & 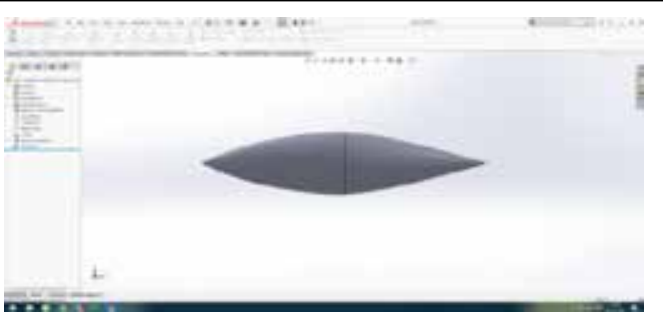 \\
\hline 4 & 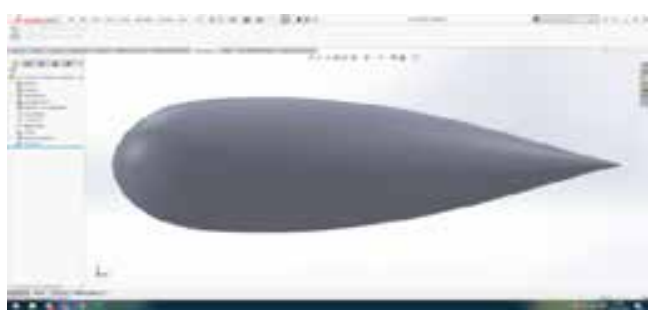 & 12 & 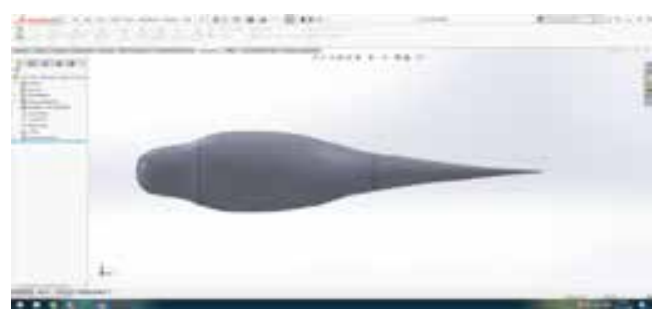 \\
\hline
\end{tabular}


Таблиця 1 (закінчення)

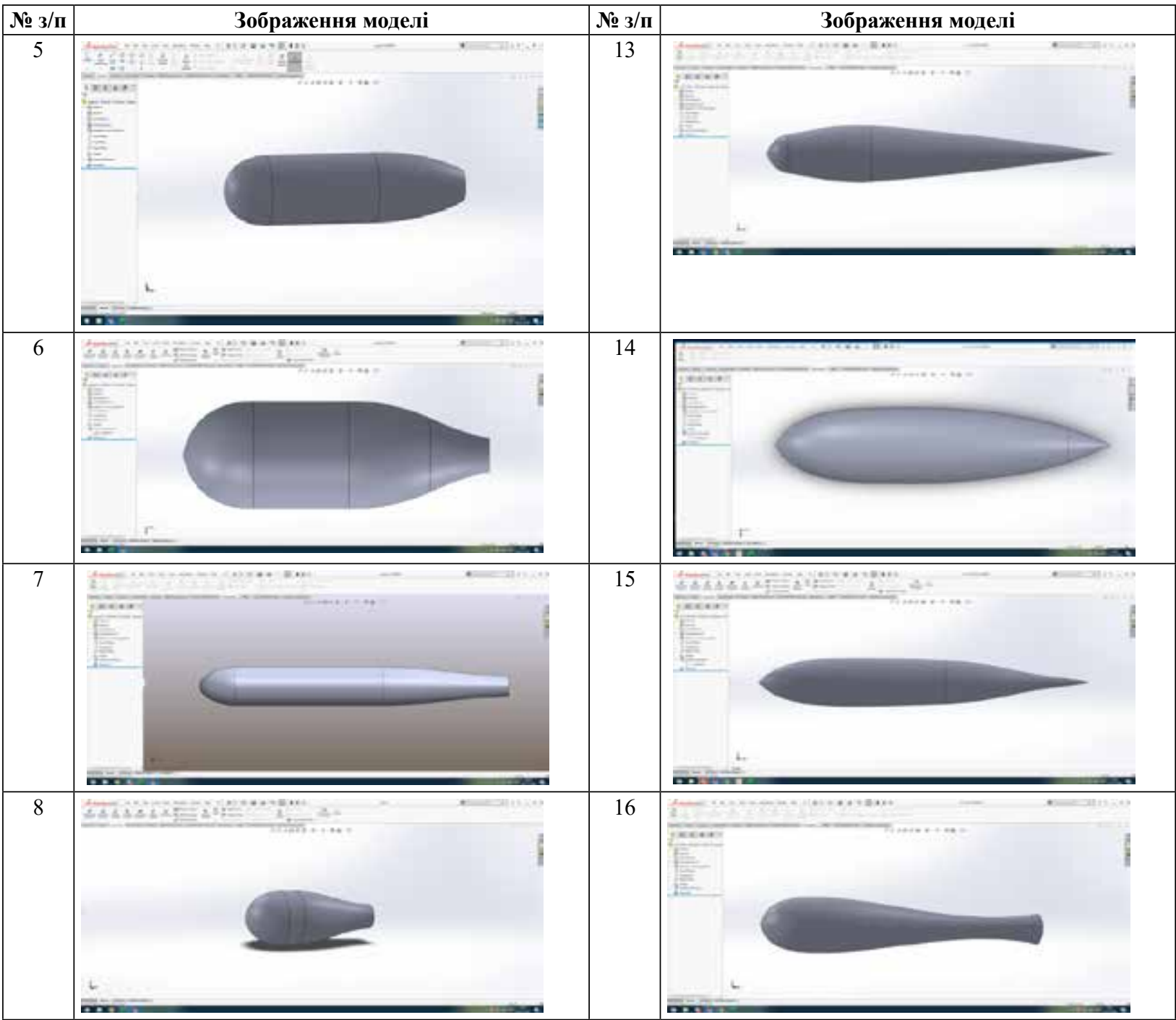

Параметри, які були досліджені за допомогою SolidWorks Professional, - це показник стресу матеріалу під тиском у водному середовищі в МПа, зсув матеріалу у мм та еквівалентна деформація матеріалу в ESTRN [6]. Еквівалентна деформація є розрахунковим показником і базується на характеристиках, наведених у табл. 2.

Еквівалентна деформація (ESTRN) визначається за формулами 1-4:

$$
\begin{gathered}
\mathrm{ESTRN}=2\left[\left(\varepsilon_{1}+\varepsilon_{2}\right) / 3\right]^{(1 / 2)}, \\
\varepsilon_{1}=0,5\left[\left(\mathrm{EPSX}-\varepsilon^{*}\right)^{2}+\left(\mathrm{EPSY}-\varepsilon^{*}\right)^{2}+\left(\mathrm{EPSZ}-\varepsilon^{*}\right)^{2}\right], \\
\varepsilon_{2}=\left[(\mathrm{GMXY})^{2}+(\mathrm{GMXZ})^{2}+(\mathrm{GMYZ})^{2}\right] / 4, \\
\varepsilon^{*}=(\mathrm{EPSX}+\mathrm{EPSY}+\mathrm{EPSZ}) / 3,
\end{gathered}
$$

Для моделювання була використана корабельна сталь AISI 316 Stainless Steel Sheet (SS) із такими характеристиками: модуль пружності: 192999,9974 N/mm², коефіціент Пуассона: 0,27 N/A, масова густина (щільність): 8000,000133 kg/m³, межа текучості: $172,3689323 \mathrm{~N} / \mathrm{mm}^{2}$, межа міцності при розтяганні
Таблиця 2. Базові характеристики для розрахунків еквівалентної деформації

\begin{tabular}{|c|c|}
\hline Позначення & Назва показника \\
\hline EPSX & Нормальна деформація по X \\
\hline EPSY & Нормальная деформація по Y \\
\hline EPSZ & Нормальная деформація по Z \\
\hline GMXY & Напруження зсуву по Y в площині YZ \\
\hline GMXZ & Напруження зсуву по Z в площині YZ \\
\hline GMYZ & Напруження зсуву по Z в площині XZ \\
\hline ESTRN & Еквівалентна деформація \\
\hline SEDENS & Щільність енергії деформації \\
\hline ENERGY & Сумарна енергія деформації \\
\hline E1 & $\begin{array}{c}\text { Нормальна деформація в першому } \\
\text { головному напрямку }\end{array}$ \\
\hline E2 & $\begin{array}{c}\text { Нормальна деформація в другому } \\
\text { головному напрямку }\end{array}$ \\
\hline E3 & $\begin{array}{c}\text { Нормальна деформація в третьому } \\
\text { головному напрямку }\end{array}$ \\
\hline
\end{tabular}


$580,0000008 \mathrm{~N} / \mathrm{mm}^{2}$, коефіціент теплового розміщення: $1,6 \mathrm{e}^{-05} \mathrm{~K}$.

Для визначення можливих кінематичних характеристик у змодельованих об'єктів було проведеного попередній аналіз їхніх геометричних параметрів. Найбільш досконалими за кінематичними характеристиками у підводному середовищі $є$ морські тварини з певними формами тіл. Дослідження, проведені для оцінки опору різних за формою біологічних тіл [7, с. 36-37], дозволяють дійти висновку, що така форма сприятлива тільки для певного діапазону чисел Рейнольдса, який відповідає найбільш швидкому режиму плавання тварини, яка має таку форму. Найбільш близькими до форм, які ламінаризувалися, є тіла форелі, тунця, акули, дельфіна, китів, що мають ламінарну ділянку, довжина якої залежить від числа Re i визначається по довжині гідробіонтів максимальної товщини.

Для швидкісних риб і китоподібних числа Рейнольдса складають $\mathrm{Re}=10^{6}-10^{8}$ [7, с. 37], що для твердих тіл відповідає турбулентному режиму обтікання і є відносно великим значенням коефіцієнта опору. Однак біоенергетичні розрахунки показують, що опір гідробіонтів значно нижчий. Однією з причин цього є ламінаризація прикордонного шару в активно плаваючих гідробіонтів, яка пов'язана зі збільшенням довжини ламінарної ділянки й істотним (у кілька разів) зниженням коефіцієнта опору.

У ламінарному прикордонному шарі в області негативного градієнту швидкості $(\mathrm{d}(\Delta \mathrm{p})) / \mathrm{dx}<0$ (область падіння тиску) від носика до найбільш широкої частини тіла у плаваючих морських тварин відбувається «розгін» потоку. Тому частки рідини, які рухаються в прикордонному шарі, мають велику кінетичну енергію в поздовжньому напрямку і більшу стійкість до різного роду поперечних збурень $[1 ; 7 ; 8]$. В області позитивного градієнту тиску $(\mathrm{d}(\Delta \mathrm{p})) / \mathrm{dx}>0$ від найбільш широкої частини тіла до кормової точки швидкість стає меншою за рахунок додаткової втрати енергії поблизу поверхні тіла, викликаної впливом сил в'язкості. Тому частинки рідини мають малу кінетичну енергію в поздовжньому напрямку і слабку стійкість до поперечних збурень. При обтіканні тіла положення точки мінімуму тиску (найбільш широка частина) впливає на становище точки переходу ламінарного в турбулентний режим течії у прикордонному шарі і слугує фізичною основою для створення ламінаризованої форми тіла.

У таких тіл найбільш широка частина, яка характеризується числом $R e=v L / v$ і перехідним режимом обтікання $R e_{\kappa p}^{\mu} \leq R e \leq R e_{k p}^{B}$, що знаходиться на певній відстані від носика тіла. Завдяки цьому прикордонний шар, що формується при обтіканні тіла потоком в'язкої рідини, зберігається ламінарним значно довш, ніж у звичайних тіл, що призводить до суттєвого зниження в'язкісного опору при змішаному режимі обтікання. Це дозволило зробити висновок, що найбільш близь- кими до форм, які ламінаризуються, є тіла форелі, тунця, акули, дельфіна, китів, що мають ламінарну ділянку, довжина якої залежить від числа $R e$ і визначається по довжині гідробіонтів максимальної товщини.

3і збільшенням числа $R e$ відносна відстань $x_{\max }$ від носика до найбільш широкої частини тіла гідробіонтів збільшується. При цьому відбувається трансформація форми носа: для відносно малих чисел ніс має повну еліптичну форму, зі збільшенням Re профіль носа набуває більш загостреної параболічної форми. Так, для форелі $\mathrm{Re}=1,2-10^{6}$ із досить повною еліптичною формою носа $x_{\max } / L=0,30$, у той час як для тунця $\operatorname{Re}=3,8-10^{7}$ із загостреною параболічною формою носа $x_{\text {max }} / L=0,50$. Для дельфінів $\mathrm{Re}=2-10^{7}$, що викликає найбільший інтерес як біологічний аналог при створенні технічних засобів руху у воді, які мають загострену форму носа i $x_{\max } / L$ яких $=0,40$ [7, с. 40$]$.

\section{ОБГОВОРЕННЯ ОТРИМАНИХ РЕЗУЛЬТАТІВ}

Теоретичний аналіз закономірностей між опором різних за формою біологічних тіл був використаний для розрахунків та оцінки відносних характеристик спроектованих моделей підводних апаратів, який наведено у табл. 3.

Таблиця 3. Оцінка відносних характеристик спроектованих моделей підводних апаратів

\begin{tabular}{|c|c|c|}
\hline Номер моделі & $\boldsymbol{x m a \boldsymbol { x } / \boldsymbol { L }}$ & Відносна товщина, \% \\
\hline 1 & 0,07 & 18 \\
\hline 2 & 0,14 & 18 \\
\hline 3 & 0,14 & 40 \\
\hline 4 & 0,23 & 38 \\
\hline 5 & 0,13 & 32 \\
\hline 6 & 0,20 & 50 \\
\hline 7 & 0,09 & 17 \\
\hline 8 & 0,20 & 60 \\
\hline 9 & 0,45 & 53 \\
\hline 10 & 0,39 & 47 \\
\hline 11 & 0,50 & 31 \\
\hline 12 & 0,26 & 28 \\
\hline 13 & 0,27 & 23 \\
\hline 14 & 0,23 & 26 \\
\hline 15 & 0,30 & 22 \\
\hline 16 & 0,19 & 25 \\
\hline
\end{tabular}

Попередньо проведені дослідження на біологічних об'єктах [7, с. 40] дозволили встановити, що $\mathrm{x}_{\max } / \mathrm{L}<0,30$ характеризує еліпсоїдну форму тулуба i відносно низькі значення коефіцієнта Re. Показники відношення $0,40<\mathrm{x}_{\max } / \mathrm{L}<0,50$ характеризують загострену параболічну форму і високі значення коефіцієнта Re. Дані табл. 3 дозволяють зробити висновки щодо проаналізованих геометричних характеристик отриманих моделей за відношенням відносної відстані $x_{\max }$ від носової частини до найбільш широкої частини моделі до їх загальної довжини $L$. Зі спроектованих профілів моделей лише моделі 9, 10, 11 і 15 відповіда- 
ють цій вимозі. Інший показник - відносна товщина природних профілів характеризує опір тіла обертання при русі. Для швидкісних гідробіонтів він знаходиться в межах $17-24 \%$ [7, с. 40-41]. При цьому опір тіла обертання досягає мінімального значення при відносній товщині у $22 \%$. За даними табл. 3 відповідні значення характерні для моделей $13,15$.

За обома аналізованими показниками модель № 15 відповідає оптимально встановленим співвідношенням для біологічних об'єктів із числом $\mathrm{Re}=10^{7}$, що забезпечує найменший опір тіла при русі. Тому саме ця модель може стати прототипом для подальших наукових розробок при проектуванні підводних роботизованих апаратів.

Проведений ретельний аналіз змін характеристик матеріалу в умовах статичного впливу тиску $0,505 \mathrm{MПа}$ у зазначених моделей на глибині 50 м дозволив дійти висновку, що у них не спостерігалося значних деформацій корпусу. Для моделі № 13 максимальні зміщення були характерними у носовій частині (1,960 $\mathrm{e}^{-02}$ мм), для моделі № 15 вони становили 1,768 $\mathrm{e}^{-02}$ мм. Зсув матеріалу в долях міліметрів не зможе спровокувати значної деформації корпусу і не вплине на зміну його міцностних характеристик, оскільки вибраний матеріал за таких умов не руйнується. Найменш вразливими до дії навколишнього середовища $є$ хвостові частини об'єктів, мінімальні зміщення в межах яких коливалися від $1,0 \mathrm{e}^{-30}$ до $1,0 \mathrm{e}^{-03} \mathrm{Mм}$.

\section{ВИСНОВКИ}

Необхідно зазначити, що форми моделей № 13 і № 15 мають добру обтічність і при встановленні відповідних рушіїв забезпечать задану швидкість. Для виключення можливого зсуву шарів матеріалу та зміцнення каркасу необхідно передбачити наявність ребер жорсткості в критичних зонах. Однак для однозначного висновку щодо характеру змін міцностних властивостей моделей, проведення нестандартного аналізу впливу середовища на об'єкт, кінетики руху моделі у водному середовищі необхідне проведення додаткових випробовувань за допомогою варіації основної програми - SolidWorks Simulation Xpress.

\section{REFERENCES}

[1] Ahmedov T.X., Brodskij A.K., Galanin I.F., Zeleev R.M. (2018) Apparaty s mashushhimi dvizhiteljami i ih prirodnye analogi [Devices with flapping movers and their natural analogues : monograf]. Moskva : Infra-Inzhenerija.

[2] Syrotynskyj O.A. (2003). Osnovy avtomatyzaciyi proektuvannya mashyn. Navchalnyj posibnyk dlya studentiv vyshhyx navchalnyx zakladiv [Fundamentals of machine design automation]. Rivne : UDUVGP. Publ. [in Ukrainian].

[3] Autodesk Inventor LT. Retrieved from: http://www.arcada.com.ua/infot/po/mech/inventor_lt.html

[4] AutoCAD Inventor LT Suite 2016. Retrieved from: https://itpro.ua/product/autodesk_Inventor_lt_2016/?tab=description.

[5] SolidWorks - svitovyj standart avtomatyzovanogo proektuvannya. Retrieved from: http://commit.name/index. php?MainShowID=104

[6] Spravka po SOLIDWORKS. Retrieved from: http://solidworks.com/2015/russian/SolidWorks/cworks/c_Strain_ Components_output_LSA.htm.

[7] Slizhevskij N.B (2002) Gidrobionika v sudostroenii : uchebnoe posobie [Hydrobionics in shipbuilding]. Nikolaev : UGMTU [in Russian].

[8] Romanenko E.V. (1986) Teorija plavanija ryb i delfinov [Swimming theory of fish and dolphins]. Moskva : Nauka [in Russian].

\section{СПИСОК ВИКОРИСТАНОЇ ЛІТЕРАТУРИ}

[1] Ахмедов Т.Х., Бродский А.К., Галанин И.Ф., Зелеев Р.М. Аппараты с машущими движителями и их природные аналоги : монография Москва : Инфра-Инженерия, 2018. 360 с.

[2] Сиротинський О.А. Основи автоматизації проектування машин. Навчальний посібник для студентів вищих навчальних закладів. Рівне : УДУВГП, 2003. 252 с.

[3] Autodesk Inventor LT. URL: http://www.arcada.com.ua/infot/po/mech/inventor_lt.html (дата звернення: 23.01.2020).

[4] AutoCAD Inventor LT Suite 2016. URL: https://itpro.ua/product/autodesk_Inventor_lt_2016/?tab=description (дата звертання: 08.09.2020).

[5] SolidWorks-світовий стандарт автоматизованого проектування. URL: http://commit.name/index.php?MainShowID=104 (дата звернення: 08.09.2020).

[6] Справка по SOLIDWORKS. URL: http://solidworks.com/2015/russian/SolidWorks/cworks/c_Strain_Components_output LSA.htm (дата звернення: 08.09.2020).

[7] Слижевский Н.Б. Гидробионика в судостроении : учебное пособие. Николаев : УГМТУ, 2002. 112 с.

[8] Романенко Е.В. Теория плавания рыб и дельфинов. Москва : Наука. 1986. 148 с. 